\title{
Coronavirus 2019 (COVID-19) Outbreak in India: A Perspective so far
}

\author{
Puneet Kumar Gupta ${ }^{1}$, Preeti Bhaskar ${ }^{2}$, Sonam Maheshwari ${ }^{3 *}$
}

${ }^{1}$ ICFAI Business School, The ICFAI University, Dehradun, India

${ }^{2}$ Ibra College of Technology, Oman \& Research Scholar, ICFAI Business School, The ICFAI University, Dehradun, India

${ }^{3}$ Department of Community Medicine, Govt. Doon Medical College, Dehradun, India

\section{Correspondence:}

Sonam Maheshwari

Address: Department of

Community Medicine, Govt. Doon Medical College, Dehradun, India

Email:

maheshwarisonam2@gmail.com
Received: 20.04.2020,

Accepted: 26.04 .2020

https://doi.org/10.5799/jcei/8220

\section{INTRODUCTION}

In December 2019, a pathogenic HCov, 2019 novel coronavirus (2019-nCoV), was recognized in Wuhan, Hubei Province, China, and has caused serious illness and death. The ultimate scope and effect of this outbreak are unclear at present as the situation is rapidly evolving [1]. The virus generated through respiratory droplets through coughing and sneezing can be killed through sanitizers.

The epidemics of COVID-2019 have been recorded over 200 countries, territories $\&$ areas along with China and pinched more than 26654 humans, affecting severely around 575, 444 cases [2]. On 11 March 2020, WHO change the status of the COVID-2019 emergency revised by the WHO within 42 days from Public Health International Emergency (January 30, 2020) to a pandemic (March 11, 2020). Nonetheless, the case fatality rate (CFR) of the current epidemic is on the rise (between $2-4 \%)$, relatively is lower than the previous SARS-CoV (2002/2003) and MERS-CoV (2012) outbreaks [3].

Since the outbreak of COVID-19, many researchers have started investing COVID-
19 from various perspectives. The researcher's community is also trying to contribute in their way to fight with the pandemic disease. Recently, Santacroce et al. [29] work on their perspectives about COVID-19 and Italy. To the best of our knowledge, this is the first study that gives a bird's eye about COVID-19 in India. However, information about this epidemic is dynamic and readers are suggested to update themselves on a daily basis.

\section{HISTORY SO FAR}

In India, the first case of COVID-19 was reported on 30th January 2020, originating from a student who travelled from Wuhan, China although successfully recovered from the infection on 14 February $2020[4,5,6]$. As of $14^{\text {th }}$ April 2020, The Ministry of Health And Family Welfare has confirmed a total of 10363 active cases, 1036 recoveries, 1 migration and 339 deaths in the country from 31 State/UT including 66 foreign cases [7]. The trend of confirmed, active, cured/discharged and death cases as on $14^{\text {th }}$ April 2020 is shown in Figure 1 [32]. The infection rate of COVID-19 in India is reported to be 1.7 , significantly lower than the worst affected countries, as on 29 March $2020[8,33-35]$. 


\section{HOW HAS COVID-19 AFFECTED INDIA IN APRIL}

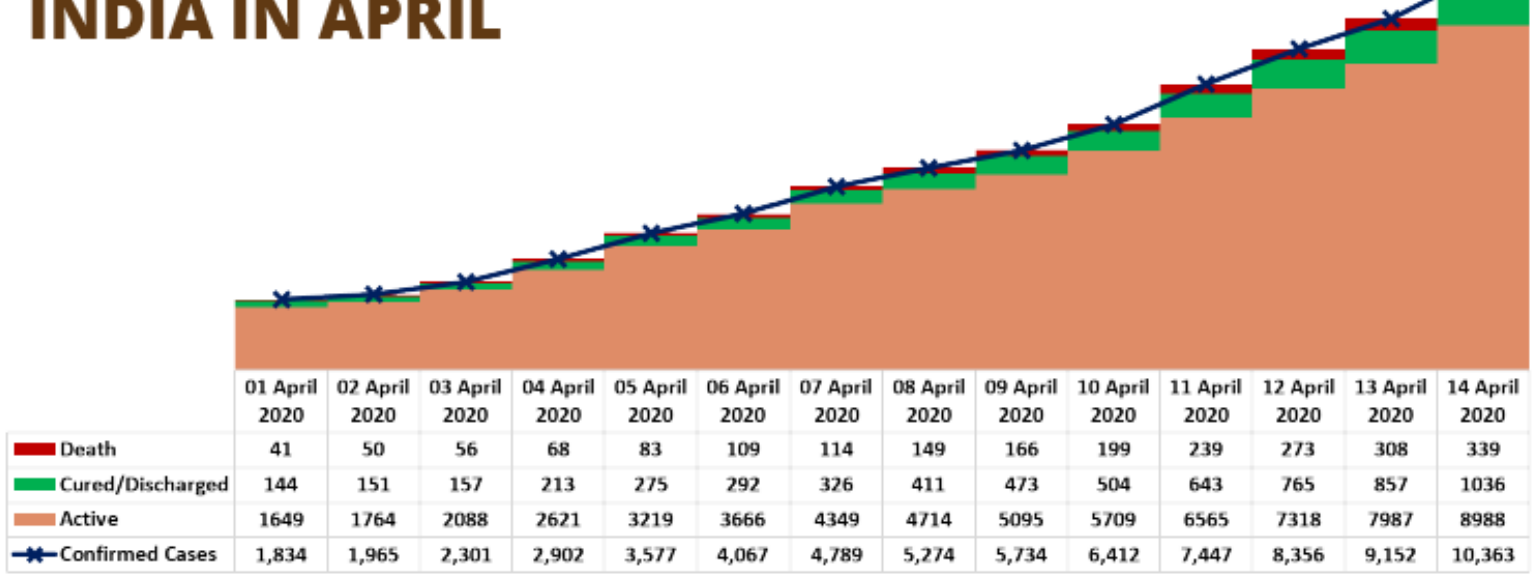

Figure 1. Trend of Confirmed, Active, Cured and Death Cases in India

Source: Ministry of Health and Family Welfare, India [32]

\section{MAJOR FOOTSTEPS SO FAR}

\section{Restrict International Air Travel}

By stating that, more than 100 countries across the world now have reported cases of COVID-19, various travel advisories had been issued by the Ministry of Health and Family Welfare from time to time. Some of the major decisions are as follows [9-11]:

- All existing visas (except diplomatic, official, UN/International Organizations, employment, project visas) stand suspended till $15^{\text {th }}$ April 2020.

- All incoming travelers, including Indian nationals, arriving from or having visited China, Italy, Iran, Republic of Korea, France, Spain, and Germany after $15^{\text {th }}$ February 2020 shall be quarantined for a minimum period of 14 days. This will come into effect from 1200 GMT on $13^{\text {th }}$ March 2020 at the port of departure.

- All international Passengers entering into India are required to furnish duly filled self-declaration form in duplicate (including personal particulars i.e. phone no. and address in India) to Health Officials and Immigration officials and undergo Universal Health Screening at the designated health counters at all Points of Entry

In addition to the above, the Directorate General of Civil Aviation (DGCA) also prohibited the Travel of passengers from member countries of the European Union, the European free trade association, Turkey and the United Kingdom to India with effect from 18th March 2020 [11]. No airline shall board passengers from these nations to India with effect from 1200 GMT on March 18, 2020. As on 6th April 2020, Amid a complete lockdown in India, there is a complete ban on international flights till 1830 hours GMT of April 14, 2020. However, the restrictions would not apply to cargo flights or those specially permitted by the Directorate General of Civil Aviation (DGCA), according to the latest advisory by the civil aviation ministry $[12,13]$.

\section{Complete Lockdown}

On 24 March, Prime Minister Narendra Modi ordered a nationwide lockdown for 21 days, but it seems to be the tip of the iceberg as a notion is that the war with the unseen virus will cause longer shutdowns. The lockdown includes schools, offices, factories, parks, temples, railway stations and even the airspace [14]. It was ordered after a 14-hour voluntary public curfew on 22 March, followed by enforcement of a series of regulations in the country's COVID-19 affected regions $[15,16]$. While announcing lockdown, India was sooner to employ lockdown as compare to other countries and that may be one of the reasons for low infected cases so far $\left(10,363\right.$ as on $14^{\text {th }}$ April 2020) in comparison to the others. The lockdown was placed when the number of confirmed positive coronavirus cases in India was approximately 500. The impact of COVID-19 and the lockdown that follows is double folded, one the Indian economy is going to suffer externally which includes: weaker global demand, supply chain disruptions, Lower commodity price, and Risk-off and Global financial shocks. Second is through the domestic channels, which include: Reduced discretionary spending, factory shutdowns, and travel restrictions.

\section{Financial Aspects}

On $1^{\text {st }}$ April 2020, RBI announces further measures for dealing with the COVID-19 pandemic. Key points are as follows (for more details see [17]):

- Extension of realization period of export proceeds

- Review of Limits of Way and Means Advances of States/UTs 
- Implementation of countercyclical capital buffer

Apart from the above major steps, the Indian Government has taken various steps to stop the spread of COVID-19 like Janta curfew, Prakash Parv, PM CARE Fund, $30 \%$ reduction in the salary of ministers for 1 year, closing educational institutes in the early stage, etc.

\section{MAJOR CHALLENGES SO FAR}

\section{Health Facilities}

COVID-19 exposed India's crumbling healthcare system where there are lacks of beds, a lack of testing kits, understaffed hospitals. Many cases were reported where patients were not tested or admitted in hospitals due to a shortage of essential medical facilities [18]. The WHO recommends a doctor-to-patient ratio of 1 doctor for 1000 patients but India needs more than 50,000 critical-care specialists, but only has 8,350 [19]. According to WHO, in India, a doctor (modern medicine) and population ratio is $0.77: 1,000$ as per current population estimate of 1.33 billion [30]. Most existing literature on $\mathrm{HRH}$ in India reports that the country is well short of the WHO's recommendation of the minimum threshold of 2.28 skilled health professionals per 1000 population [31]. The ICMR has permitted 51 private labs to conduct tests for COVID-19 and given that less than 50,000 for more than 1.3 billion population [20]. The government failure to competently deal with the COVID crisis has reached a point where government doctors have publicly expressed their concerns about the pandemic situation. Healthcare professionals including doctors, nurses, and staff are facing shortages of personal protective equipment as cases rising every day. There is a sense of alarm among healthcare professionals who believe that there will be a tsunami of coronavirus cases. In India, Quarantine centres are another challenge where the actual numbers are fairly less than the required numbers. Many people have escaped quarantine centres complaining of inadequate facilities, unhygienic conditions, stained toilets, broken beds, and the risk of getting the COVID-19 illness. The government along with private player are putting their efforts to provide facilities to the Quarantine person, but efforts seem to be not sufficient. A lot of images and posts were shared on social media about the poor health care infrastructure at quarantine centres [21]. Looking at the current situation, it has become a challenge for India to keep up With COVID-19.

\section{Tablighi Jamat}

The Tablighi Jamaat has been at the centre of a controversy, after dozens of people who attended a religious congregation in Delhi in March and were tested positive for COVID-19. Around 2,000 people, both from across the country and foreign nations had attended the gathering [22]. Coronavirus cases have increased nearly by 3 times after the Tablighi Jamaat event and likely to reach 1.5 lakh by May first week [23]. The possibilities of community transmission of the fatal virus have increased after Tablighi Jamaat, where a large number of people are still not been traced. The government carelessness is also blamed for its negligence when Ijtema Tablighis in Mumbai was stopped on March 14, but the Jamaat event was conducted on March 30.in Delhi. The Delhi police had booked Maulana Saad Kandhalvi, leader of the group under the Epidemic Disease Act. The Central Joint Secretary called for a complete ban on their movement, freeze the bank accounts but also locked down their offices for further activities further [24]. All foreign nationals are who have attended this event are quarantined in Delhi [25].

\section{Migrant Workers}

The sudden lockdown across the country had affected around 45 million economic migrant workers who are now forced to make a long, arduous journey back to their rural villages [26]. The journey was fatal for migrant workers, died, facing hunger, many lost their jobs and have shut down the shops. The pervasive challenge is that these migrants could spread the coronavirus from urban areas to rural areas, where there are not enough hospitals for treating coronavirus pandemic India's finance minister sanction more than $\$ 22$ billion in coronavirus relief money [27]. The government, private companies, NGOs and volunteers are trying to provide facilities like transport, accommodation, food, money, etc. to make their journey easy. IndianAmerican non-profit body launches initiative for underprivileged communities in India to serve and protect underprivileged communities to fight against the coronavirus pandemic, and help them emerge strongly through a social and economic crisis [28]. Many economists say these initiatives are not sufficient, they need a larger inducement to maintain medical facilities, basic amenities, monetary support and a strong supply chain for maintaining basic amenities.

\section{CONCLUSION}

The government of India is taking all necessary steps to ensure that we are prepared well to face the challenge and threat posed by the growing pandemic of COVID-19. India's response mechanisms are being closely watched by its country national and the rest of the world. The early announcement of a lockdown, social distancing, travel restriction, suspension of flights trains and bus services, cancellation of Visas, converted coaches of Indian Railways as isolation wards are few such important measures which have been widely appreciated. The government is also looking for active support from the citizen in this epidemic situation by following the guidelines and measures announced by the respective authorities. The government is empowering the citizens with the right information and regularly updating the citizen through various media channels. Doctors and paramedics are working to the best of their services. Private players, NGOs, and volunteers have also contributed in many ways. As we are in the third week of lockdown, Indians have followed the government rules by 
understanding their responsibility positively. India is still facing many challenges like shortage of health care facilities, untraced COVID cases, health care staff, etc. The availability of government beds is abysmally low in India, and an epidemic like coronavirus can very quickly complicate the problem even further. India had only 111 Covid-19 testing centers to handle a population of 1.35 billion people. The number of beds in government-run quarantine facilities across the country is about 60,000 . As a result, most patients have been relying on understaffed, underfunded and lack resources to run medical facilities [36]. Without strong healthcare facilities, Country can't combat epidemics with the required degree of effectiveness and equity. The government has performed therapeutic protocols for dealing with COVID-19. Ministry of Health \& Family Welfare issued guidance document on appropriate management of suspect/confirmed cases of COVID-19 by Dedicated Facilities into three types i.e. COVID Care Center (CCC), Dedicated COVID Health Centre (DCHC), and Dedicated COVID Hospital (DCH) [37]. All 3 types of COVID Dedicated facilities have separate areas for suspect and confirmed cases to avoid under any mix in any circumstances. All these facilities follow strict infection prevention and control practices by following the protocol for managing the COVID-19 cases. Suspect and confirmed cases clinically assigned as severe (Dedicated COVID Hospital. If test results are positive, such patient will remain in COVID-19 ICU and receive treatment as per standard treatment protocol. Patients testing negative will be managed with adequate infection prevention and control practices. The Indian Council of Medical Research has started clinical trials to explore convalescent plasma therapy as a potential treatment for the Covid-19 patients. They got approval from Drug Controller General clinical trial of plasma therapy for Covid-19 patients [38]. There is still more need to be done to revive the economy in all aspects. This is neither the first challenge nor the final one which India has faced when the natural ecological milieu is disturbed. What goes the future of COVID-19 in India is not known but one thing is for sure if we follow social distancing protocol and advisories strictly, we can make way for lives of ours and our dear ones and can prevent the coming cyclone hovering over India right now. At present best prophylaxis is conveyed by one sentence being used globally "stay home, stay safe" apart from taking other recommended precautions.

Declaration of interest: The authors report no conflicts of interest. Financial Disclosure: No financial support was received.

\section{REFERENCES}

1. Paules CI, Marston HD, Fauci AS. Coronavirus infections-more than just the common cold. Jama. 2020 Feb 25;323(8):7.
2. World Health Organization. Coronavirus disease (COVID-19) Pandemic. 2020. Available at: https://www. who.int/emergencies/diseases/novel-coronavirus-2019 (Accessed: 29 March 2020).

3. Malik YS, Sircar S, Bhat S, Vinodhkumar OR, Tiwari R, et al. (2020). Emerging Coronavirus Disease (COVID19), a pandemic public health emergency with animal linkages: Current status update. Available at: https://www.preprints.org/manuscript/202003.0343/do wnload/final_file

4. COVID19 India. 2020. Available at: https://www.covid 19india.org/ (Accessed: 29 March 2020).

5. Pinarayi Vijayan 2020, Update on Coronavirus incident: A patient has been tested positive for Novel Coronavirus infection and is kept in isolation. The infected patient is a student of Wuhan University. We are closely monitoring the situation, Tweet, 30 January. Available at: https://twitter.com/vijayanpinarayi/status/12228194 65143832577

6. The Weather Channel. Kerala Defeats Coronavirus; India's Three COVID-19 Patients Successfully Recover. Available at: https://weather.com/en-IN/india/news/ news/2020-02-14-kerala-defeats-coronavirus-indiasthree-covid-19-patients-successfully (Accessed: 29 March 2020).

7. Ministry of Health and Family Welfare, Government of India. 2020. Available at: https:/www.mohfw.gov.in

8. Wikipedia. 2020 coronavirus pandemic in India. 2020. Available at: https://en.wikipedia.org/wiki/2020_corona virus_pandemic_in_India\#cite_note-:2-8 (Accessed: 29 March 2020).

9. Ministry of Health and Family Welfare, Government of India. 2020 Available at: https://www.mohfw.gov.in/ pdf/ConsolidatedTraveladvisoryUpdated11032020.pdf (Accessed: 6 April 2020).

10. Bureau of Immigration, Ministry of Home Affairs, Government of India. 2020. Available at: https://boi.gov. in/content/advisory-travel-and-visa-restrictionsrelated-covid-19-0 (Accessed: 6 April 2020).

11. The Economic Times. Now, India bans entry of Indians from EU, Turkey and UK. 2020. Available at: https://economictimes.indiatimes.com/news/politicsand-nation/government-prohibits-entry-of-passengersfrom-eu-turkey-uk-from-march-18/articleshow/74657 194.cms?utm_source=contentofinterest\&utm_medium =text\&utm_campaign=cppst (Accessed: 6 April 2020).

12. Business Today. Coronavirus outbreak: India extends ban on international flights till April 14. 2020 Available at: https://www.businesstoday.in/sectors/aviation/coro navirus-outbreak-india-extends-ban-on-internationalflights-till-april-14/story/399343.html (Accessed: 6 April 2020). 
13. Shroff N. India extends ban on international flights until April 14. 2020. Available at: https://www.business traveller.com/business-travel/2020/03/27/india-extends -ban-on-international-flights-until-april-14/ (Accessed: 6 April 2020).

14. Gettleman J, Schultz K. Modi Orders 3-Week Total Lockdown for All 1.3 Billion Indians. The New York Times. 2020. Available at: https://www.nytimes.com/20 20/03/24/world/asia/india-coronavirus-lockdown.html (Accessed: 6 April 2020).

15. UN News. COVID-19: Lockdown across India, in line with WHO guidance. 24 March 2020. Available at: https://news.un.org/en/story/2020/03/1060132 (Accessed: 6 April 2020).

16. Regan H, Mitra E, Gupta W. India places millions under lockdown to fight coronavirus. CNN. Available at: https://edition.cnn.com/2020/03/23/asia/coronaviruscovid-19-update-india-intl-hnk/index.html (Accessed: 6 April 2020).

17. Reserve Bank of India, Mumbai. RBI announces further measures for dealing with the COVID-19 pandemic. 2020. Available at: https://rbidocs.rbi.org.in/rdocs/ PressRelease/PDFs/PR2167BA409AC37FA8460497BA0 C9B283E5DD9.PDF (Accessed: 6 April 2020).

18. Krishnan V. Lack of testing kits, understaffed hospitals: COVID exposes India's crumbling healthcare system. 2020. Available at: https://caravanmagazine.in/health/ lack-testing-kits-understaffed-hospitals-covid-exposesindia-crumbling-healthcare-system (Accessed: 6 April 2020).

19. Kumar R, Pal R. India achieves WHO recommended doctor population ratio: A call for paradigm shift in public health discourse!. Journal of Family Medicine and Primary Care. 2018 Sep;7(5):841.

20. Rajagopal D. Covid-19: Private labs face home testing hiccups. 2020 Available at: https://m.economictimes. com/industry/healthcare/biotech/healthcare/covid-19private-labs-face-home-testing-hiccups/articleshow/ 74940906.cms (Accessed: 6 April 2020).

21. Sarkar S. Coronavirus quarantine in India: no tests, stained toilets and broken beds force some to flee. 2020 . Available at: https://www.scmp.com/week-asia/healthenvironment/article/3076896/coronavirus-quarantineindia-unhygienic-facilities (Accessed: 6 April 2020).

22. Johny S. Explained / Who are the Tablighi Jamaat? 2020. Available at: https://www.thehindu.com/news/national/ explained-who-are-the-tablighi-jamaat-the-organisatio n-at-the-epicentre-of-coronavirus-outbreak-in-india/ article31238915.ece (Accessed: 6 April 2020).

23. Anand A. IIM study predicts 1.5 lakh Covid- 19 cases by May first week as 'result of Tablighi event'. 2020. Available at: https://theprint.in/india/iim-study-predict s-1-5-lakh-covid-19-cases-by-may-first-week-as-resultof-tablighi-event/397810/ (Accessed: 6 April 2020).
24. Mishra A. Coronavirus: VHP demands complete ban on Nizamuddin Markaz, Tablighi Jamaat. 2020. Available at: https://www.deccanherald.com/national/nationalpolitics/coronavirus-vhp-demands-complete-ban-onnizamuddin-markaz-tablighi-jamaat-821721.html (Accessed: 6 April 2020).

25. BBC News. Tablighi Jamaat: The group blamed for new Covid-19 outbreak in India. 2020. Available at: https://www.bbc.com/news/world-asia-india-52131338 (Accessed: 6 April 2020).

26. Rukmini S. India's coronavirus lockdown takes toll on migrant workers. Available at: https://www. aljazeera.com/news/2020/03/india-fight-coronavirustakes-toll-migrant-workers-200324084150540.html (Accessed: 6 April 2020).

27. Choudhury SR. India announces $\$ 22.5$ billion stimulus package to help those affected by the lockdown. 2020. Available at: https://www.cnbc.com/2020/03/26/ coronavirus-india-needs-a-support-package-largerthan-20-billion-dollars.html (Accessed: 6 April 2020).

28. PTI. COVID-19: Indian-American body launches initiative for underprivileged communities in India. Available at: https://www.deccanherald.com/inter national/covid-19-indian-american-body-launchesinitiative-for-underprivileged-communities-in-india821194.html (Accessed: 6 April 2020).

29. Santacroce L, Charitos IA, Del Prete R. COVID-19 in Italy: An Overview from the First Case to Date. Electron J Gen Med. 2020;17(6):em235. doi: 10.29333/ejgm/7926.

30. Density of Physicians (Total Number per 1000 Population, Latest Available Year), Global Health Observatory (GHO) Data. Situation and Trends. Available at: http://www.who.int/gho/health_workforce /physicians_density/en/

31. Anand S, Fan V. The health workforce in India. Geneva: World Health Organization; 2016 (Human Resources for Health Observer Series No.16. Available at: https://www.who.int/hrh/resources/hwindia_healthobs16/en/ (Accessed: 25 April 2020).

32. Ministry of Health and Family Welfare, Government of India. Available at: https://community.data.gov.in/covid -19-india-factsheet-as-on-14th-april-2020-900-am/ (Accessed: 16 April 2020).

33. CTBUREAU_NAV. Covid-19 cases rise to 5,194 with 149 deaths in India. citytoday. 2020. Available at: https:// citytoday.news/covid-19-cases-rises-to-5194-with-149deaths-in-india-181-cases-5-deaths-in-karnataka/ (Accessed: 16 April 2020).

34. Shaik I. Contribution of Indian Leadership in war against COVID-19. TimesofIndia. 2020. Available at: https://timesofindia.indiatimes.com/readersblog/drisrar-shaik/contribution-of-indian-leadership-in-waragainst-covid-19-11786/ (Accessed: 16 April 2020). 
35. Dutta PK. Is coronavirus situation in India less severe than other countries?. India Today. 2020. Available at: https://www.indiatoday.in/coronavirus-outbreak/story/ is-coronavirus-situation-in-india-less-severe-thanother-countries-1661359-2020-03-30 (Accessed: 16 April 2020).

36. Changoiwala P. Covid-19 Threatens to Overwhelm India's Health Care System. Undark. 2020. Available at: https:/undark.org/2020/04/14/covid-19-india/
37. Ministry of Health and Family Welfare, Government of India. Guidance document on appropriate management of suspect/confirmed cases of COVID-19. Available at: https://www.mohfw.gov.in/pdf/FinalGuidanceonMang aementofCovidcasesversion2.pdf (Accessed: 26 April 2020).

38. Porecha M. DCGI clears clinical trial of plasma therapy in Covid-19 patients. BusinessLine. 2020. Available at: https://www.thehindubusinessline.com/news/national/ drug-controller-general-of-india-approves-clinicaltrial-of-convalescent-plasma-therapy-in-covid-19patients/article31375934.ece (Accessed: 26 April 2020). 